\title{
THEORETICAL CONSIDERATIONS FOR AN ARTIFICIAL CORNEAL IMPLANT*
}

\author{
BY \\ O. E. E. ANDERSON \\ San.Francisco, Calif., U.S.A.
}

THE operation of keratoplasty, which offers such dramatic restoration of vision in appropriate cases, is not carried out as often as it might be for two principal reasons. First, the supply of suitable human corneae is limited, and secondly, in many instances the graft ultimately becomes as opaque as the recipient cornea.

The patent way to attempt to circumvent these difficulties is to place in the leukomatous cornea a port of transparent abiotic material. It is not surprising that operations of this type have been undertaken, the first nearly a century ago. Such ports were implanted in corneae by Nussbaum (1853), Heusser (1860), von Hippel (1877), Dimmer (1889), Baker (1889), van Millingen (1895), Salzer (1895), Franceschetti (1949), Gyorffy (1951), and others. In most cases these were successful for short periods, but the eyes were later damaged by infection or unspecified degenerations. The implants used were of glass or plastic, and were retained by flanges of the same material, or of metal, resting on the surface of the epithelium and/or endothelium.

The recent work of Bick (1949) and Parry (1950) demonstrated the tolerance of tantalum by the ocular tissues. This, together with glass-to-metal sealing techniques common in the electronics industry, suggests a new approach to the mechanical aspect of the problem.

\section{Projected Design}

On contemplating the design of an artificial corneal implant, a number of desiderata present themselves:

(1) The materials should be biologically inert.

(2) The implant should be flush with the anterior surface of the cornea. Any protrusion would chafe the palpebral conjunctiva, and lid motion would tend to move the implant, irritating the supporting corneal tissue.

(3) The implant should likewise be substantially flush with the posterior surface of the cornea, not only to preserve as deep an anterior chamber as possible, but also to minimize the possibility of the implant's coming into contact with the iris or lens.

* Received for publication May, 21, 1951. 
(4) Support for the implant should be furnished by the stroma of the cornea, rather than by the epithelium and/or endothelium, as this is tougher, less subject to inflammation, and less sensitive.

(5) The anchorage of the implant should be able to withstand tensile and flexural stresses, so that it is not loosened by any transient deformation of the globe.

(6) The seal between implant and cornea should be adequate to maintain the intra-ocular pressure, and to prevent the ingress of micro-organisms.

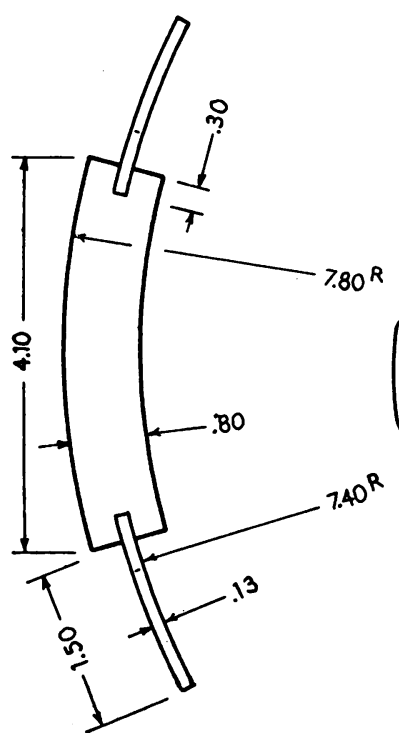

(a)

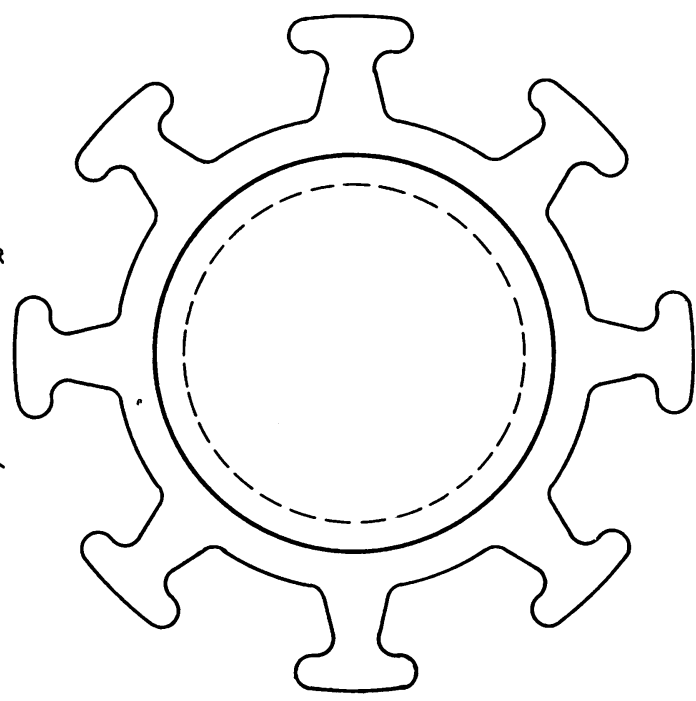

(b)

FIG. 1.-(a) Vertical section through proposed implant. Principal dimensions in millimetres. (b) Front view of proposed implant.

Fig. 1 shows a suggested design for an implant to meet these requirements. The transparent portion is of glass, of approximately the same thickness and radii of curvature as the average cornea. (As a refinement, emmetropia could be approached by individualized selection of the curvatures.) Surrounding and sealed into the glass is a tantalum flange, formed to the corneal curvature and provided with anchoring lugs. Its thickness is the minimum consistent with mechanical considerations. As the glass alone may be assumed to have negligible refractive power, merely forming the anterior boundary of the aqueous, its refractive index and dispersive power are of little consequence. Its coefficient of expansion, however, is critical, in that it must be substantially the same as that of the tantalum which is $6.7 \times 10^{-6}$. Macbeth-Evans flask glass, for example, having a coefficient of $6.9 \times 10^{-15}$, should form a good seal with the tantalum (Hodgman, 1950). The conditions of use to which this seal may be subjected will not be nearly so severe as those encountered in electronic or chemical practice, as the temperature 
variation will be but a few degrees, and the maximum hydrostatic pressure less than $2.5 \mathrm{lb}$. per sq. in. The principal steps in making the implant are shown in Fig. 2.

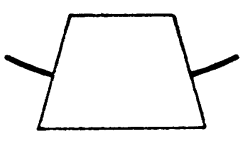

(a)

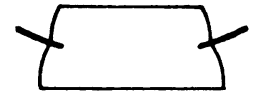

(b)

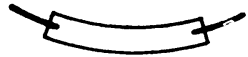

(c)

Fici. 2.- Suggested method for making implants of this design; in section. (a) The tantalum flange is placed over a truncated cone of glass.

(b) The assembly is heated to the softening point and compressed longitudinally, thus expanding the glass radially and forming a shoulder on each side of the metal.

(c) After annealing, the glass is ground to the required curvature and thickness.

\section{TECHNIQUe}

At installation, the recipient cornea is trephined to a diameter of $4.0 \mathrm{~mm}$. and split, as nearly as possible in the middle, to a depth of about $1.5 \mathrm{~mm}$. all the way around. Two or three radial cuts in the anterior half may be necessary to allow the tantalum flange to be placed in the split. Because of the splitting, suturing is apt to be difficult. The work of Tassman (1950) and of Town and Naidoff (1950) suggests that it would be desirable to use "physiological glue" (autogenous plasma plus thrombin), not only to assure rapid healing, but also to encourage corneal tissue to proliferate snugly about the metal, particularly between the lugs and adjacent to the glass, where the path of possible leakage is shortest. In these regions it might prove necessary to serrate. perforate, or roughen the metal to improve adhesion. This point, as well as the resistance of the glass to etching by the lacrimal fluid, may be determined in a series of animal experiments. It would seem advisable to inject saline into the anterior chamber after installation to prevent the implant from touching the iris or lens. Scheie and Frayer (1950) consider the use of air in the anterior chamber to be hazardous.

\section{REFERENCES}

BAKER, A. R. (1889). Amer J. Ophthal., 6, 1.

Bick, M. W. (1949). Aich. Ophthal., Chicago, 42, 373.

Dimmer, F. (1889). Ber. ophthal. Ges., Heidelberg, 20, 148.

FrancesChetti, A. (1949). Trans. ophthal. Soc. U.K., 69, 17.

GyorfFy, I. (1951). Amer. J. Ophthal., 34, 757.

Heusser (1860). Aertzl. Intelligenzbl., 7, No. 24, p. 344.

vON HipPEl, A. (1878-91). Cited by A. E. Forster (1923) in Amer. J. Ophthal., 6, 366.

Hodgman, C. D., ed. (1950). "Handbook of Chemistry and Physics" 32nd ed., pp. 1849-51. Chemical Rubber Publishing Co., Cleveland.

van Millingen, E. (1895). Atti XI Congr. med. int., Rome, 1894, vol. 6, p. 26.

Nussbaum, J. N. (1853). Z. wissensch. Zool., 5, 179.

PARRY, T. G. W. (195'). British Journal of Ophthalmology, 34, 684.

Salzer, F. (1895). Ber. ophthal. Ges., Heidelberg, 24, 230.

SCHeIE, H. G., and FraYer, W. (1950). Arch. Ophthal., Chicago, 44, 691.

Tassman, I. S. (1950). Amer. J. Ophthal., 33, 870.

Town, A. E., and NAIDOFF, D. (1950). Ibid., 33, 879. 